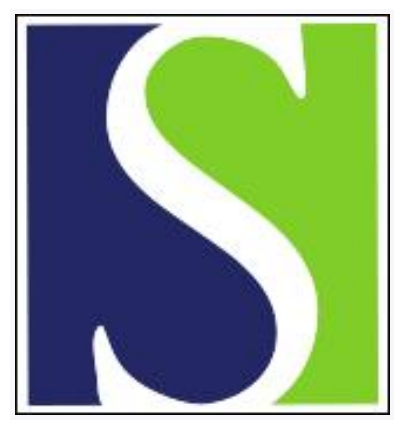

Scand J Work Environ Health 2001;27(6):365-372

https://doi.org/10.5271/sjweh.628

Issue date: Dec 2001

\title{
Contingent employment, health and sickness absence
}

by Virtanen M, Kivimäki M, Elovainio M, Vahtera J, Cooper CL

Affiliation: Finnish Institute of Occupational Health, Department of Psychology, Topeliuksenkatu 41 a A, FIN-00250 Helsinki, Finland. marianna.virtanen@ttl.fi

Refers to the following texts of the Journal: 1999;25(6):597-604

1997;23 suppl 3:79-83

The following articles refer to this text: 2008;34(2):83-95;

2008;34(4):260-266; SJWEH Supplements 2008;(6):98-110

Key terms: absenteeism; contingent employment; employment status; health; health psychology; hospital staff; job insecurity; mental health; perceived health; sickness absence; temporary employment

This article in PubMed: www.ncbi.nlm.nih.gov/pubmed/11800323 


\title{
Contingent employment, health and sickness absence
}

\author{
by Marianna Virtanen, MA, ${ }^{1}$ Mika Kivimäki, PhD, ${ }^{2}$ Marko Elovainio, PhD, ${ }^{3}$ Jussi Vahtera, MD, ${ }^{4}$ \\ Cary L Cooper, $P h D^{5}$
}

\begin{abstract}
Virtanen M, Kivimäki M, Elovainio M, Vahtera J, Cooper CL. Contingent employment, health and sickness absence. Scand J Work Environ Health 2001;27(6):365-372.

Objectives This study explored the health and sickness absences of contingent employees.

Methods Analyses of self-reported health and recorded spells of sickness absence were based on a cohort of 5650 employees (674 men, 4976 women) in 10 Finnish hospitals.

Results After adjustment for demographic and work-related characteristics, contingent employees had a better self-rated health status [odds ratio $0.76,95 \%$ confidence interval $(95 \% \mathrm{CI}) 0.62-0.94$ of poor or average health status]. There were no differences in the prevalence of diagnosed chronic diseases and minor psychiatric morbidity between the groups. After adjustment for self-rated health and confounding, female, but not male, contingent employees had a lower rate of self-certified (1-3 days) sickness absences than permanent employees (rate ratio $0.90,95 \%$ CI $0.85-0.95$ ). Contingent employees, irrespective of gender, had a 0.77 (95\% CI $0.71-$ 0.84 ) times lower rate of medically certified ( $>3$ days) sickness absence than permanent employees. Poor selfrated health status, reported diagnosed chronic diseases, and minor psychiatric morbidity were associated with medically certified absences to a less extent among contingent employees than among permanent employees. Conclusions These findings suggest better self-rated health and a lower sickness absence rate for contingent employees than for permanent employees. The difference in sickness absence between the groups seems not only to be associated with actual differences in health, but also with different thresholds of taking sick leave or working while ill.
\end{abstract}

Key terms absenteeism, employment status, health psychology, hospital staff, job insecurity, mental health, perceived health, temporary employment.

Rapid changes in worklife have led to the growth of various types of contingent employment, including fixed-term and temporary employment. Although there are several types of contingent employment arrangements, contingent work is typically limited in duration (1). In the European Union, contingent employment accounts for $12-15 \%$ of paid employment (2). Currently, the labor force seems to differentiate according to a center-periphery structure, in which a "core" consists of nearly $70 \%$ of the workforce, with a "barrier" of contingent workers (about 12\%), self-employed workers (10\%), and unemployed persons (10\%) (3).
Although the proportion of employees in the barrier is relatively large, not much is known about their health or sickness absence. Job insecurity has been found to be a potential stressor in contingent work $(1,4-6)$, and it has been shown to have an adverse effect on health and well-being (7-11).

The work conditions and motives for contingent work may vary considerably (2). Indeed, the results of previous studies on the health and well-being of contingent workers are controversial. A Swedish study on hospital staff indicated that somatic complaints were less frequent among nonpermanent workers than among

Finnish Institute of Occupational Health, Helsinki, Finland.

University of Helsinki, Department of Psychology, Helsinki, Finland.

National Research and Development Centre for Welfare and Health, Helsinki, Finland.

Finnish Institute of Occupational Health, Turku, Finland.

University of Manchester Institute of Science \& Technology, Manchester School of Management, Manchester, United Kingdom.

Reprint requests to: Marianna Virtanen, Finnish Institute of Occupational Health, Department of Psychology, Topeliuksenkatu 41 a A, FIN-00250 Helsinki, Finland. [E-mail: marianna.virtanen@ttl.fi] 
permanent ones. No difference was found in mental distress between the two groups (1). In a random sample of employees from 15 European countries (12), contingent employees reported more job dissatisfaction, workrelated fatigue and musculoskeletal symptoms, but less stress than permanent employees. A study on a patient sample showed that temporary employment was associated with psychological health problems (13).

One dimension of employee health and well-being is absence from work. Besides medical reasons (14), many studies have found associations between absence from work and several other factors, such as attitudes toward work, biographical factors, organizational features, and job content (15). For example, job insecurity and the threat of unemployment have increased the likelihood of long-term absenteeism among employees (10, $11,16)$.

To date, sickness absence among contingent workers has been examined in only two studies, both of which were based on self-reported data. The first study focused on employees in 15 European countries (12), and no significant differences were found in work-related sickness absence between fixed-term full-time workers and permanent ones. However, fixed-term parttime employees and those working on a temporary employment agency contract reported lower levels of absenteeism than permanent workers did. Presenteeism $(17,18)$, a tendency to come to work despite illness, was investigated in a Swedish study (19). No difference in self-reported presenteeism was found between time-restricted employees and those in permanent positions.

The aim of this study was to compare self-reported health status and recorded sickness absence between contingent and permanent employees. Considering demographic factors, contingent workers have been treated as a rather homogeneous group in earlier research $(1,12,13,19)$. In this study, health status was studied by taking into account demographic and occupational confounding factors in order to minimize the confounding effects on the results. Furthermore, we have used employers' records on sickness absence instead of selfreported data to increase the reliability of the measurement (15). Finally, this is the first study to investigate the potential interaction between sickness absence and health perceptions.

\section{Subjects and methods}

This study was carried out in all 10 hospitals of two Finnish hospital districts (Varsinais-Suomi, KantaHäme), consisting of one university teaching hospital, one central hospital, and eight regional hospitals. These hospitals offer specialized health care for 614000 inhabitants (12\% of the total Finnish population). Approval of the ethics committee of the Finnish Institute of Occupational Health was obtained for the study.

We used employers' records to identify all of the 7375 employees with a job contract in the service of these hospitals at the time of this study. A questionnaire including measures on health and personal background, together with a self-addressed stamped return envelope, was sent to these employees in the beginning of 1998 . A total of 5668 (77\%) identifiable employees responded to the questionnaire. Their mean age was 44 (range 19-63) years. Nurse was the most common occupation (50\%), followed by maintenance staff (14\% - cleaners, restaurant staff, technicians, etc), laboratory and Xray personnel (13\%), administrative staff $(12 \%)$, physicians $(7 \%)$, and other professionals (4\%). Missing information on job contract was found in 18 responses, which were excluded from the analyses.

A total of 1264 (22\%) of the respondents had a contingent job contract. This proportion is close to the corresponding proportion of the eligible population (25\%) and of health sector personnel in Finland (21\%) (20). The proportion of contingent workers within the occupational groups varied from 19-20\% (laboratory and Xray personnel, other professionals, administrative and maintenance staff) to $24 \%$ (nurses) and 27\% (physicians); $6 \%$ of the respondents had a part-time job (14\% of contingent employees, $3 \%$ of permanent employees). The mean organizational tenure was 6 (SD 6.3) years and 17 (SD 8.6) years for the contingent and permanent employees, respectively.

\section{Measurements}

Information on the participants' employment status was obtained from the employers' registers. Employment status comprised the two categories of contingent (fixedterm employees and substitutes) and permanent. Workers employed by temporary help agencies were not included in this study.

Data on sickness absence were also obtained from the employers' registers. All sick-leave certificates, irrespective of where they are issued, must be forwarded for recording. For sickness absences of up to 3 days, employees may complete their own certificates. Medical certificates are required for sickness absences of more than 3 days. Employees are paid their full salary during periods of sick leave, and the social security for a sick leave is similar for both contingent and permanent employees after 1 month's employment by the same employer (21). Maternity leaves and absences due to caring for a sick child are not included in sickness absences.

All of the participants' sickness absences were obtained between 1 January 1998 and 31 December 1999. 
The records were checked for inconsistencies. Overlapping or consecutive spells of sickness absence were combined. Periods of absence due to sickness were divided into short ( $\leq 3$ days) and long ( $>3$ days) spells. The number of contracted days represented "days at risk", from which the number of days absent from work for reasons other than sickness was subtracted.

Self-rated health was the respondents' overall assessment of their health on a 5 -point scale $(1=$ poor, $2=$ rather poor, $3=$ average, $4=$ rather good, $5=$ good). The measure was dichotomized by grouping response scores 1-3 into the category of poor or average health and rating scores 4 and 5 as good health. A global rating of health has consistently proved to be an independent predictor of mortality, despite the inclusion of numerous specific health status indicators and other covariates known to predict mortality (22). A dichotomized measure is widely used in medical, epidemiologic, and health psychological research. It has also been a powerful predictor of mortality and morbidity (22-26) and has been found to be inversely associated with the number of physician contacts per year (26).

The prevalence of reported diagnosed chronic diseases was derived from a list of 14 common diseases (eg, asthma, rheumatoid arthritis, diabetes, cardiovascular disease). From this information, a dichotomous measure was calculated for whether the respondent had a disease or not. The prevalence of diagnosed diseases has predicted sickness absence in earlier studies $(10,27)$.

Minor psychiatric morbidity was measured by the General Health Questionnaire (GHQ-12) screening score (28). The focus of the GHQ has the following two dimensions: (i) an individual's capacity in everyday life and (ii) changes that have taken place in an individual's mental well-being during the past few weeks. The respondent rates each of the 12 items on experienced symptoms $(0=$ not at all, $1=$ the same as usual, $2=$ rather more than usual or $3=$ much more than usual). In the present sample, the GHQ-12 was used as a dichotomous measure in which persons who rated 2 or 3 in at least four items of the total measure were identified as cases. The General Health Questionnaire is a well-established screening measure for minor psychiatric morbidity (29).

Of the demographic variables, age, gender, occupation, and income were obtained from the registers. Marital status (married or cohabiting versus not), having at least one child under 10 years of age in the household, workhours (full-time or part-time work), work schedule (day work or shift work), and organizational tenure (number of years that the respondent had worked for the present employer) were based on survey responses.

\section{Statistical analysis}

Descriptive statistics were calculated for each of the variables. Logistic regression models were used to cal- culate the odds ratios of the health outcomes for the contingent employees in comparison with those of the permanent employees. In addition to being adjusted for gender, the odds ratios and their $95 \%$ confidence intervals ( $95 \%$ CI) were adjusted for background variables that were remarkably different in the two employment groups (age, marital status, having children under 10 years of age, occupational group, hours of work and work schedule). Interaction terms were applied to test whether the associations between employment status and health were dependent on gender. The rates of sickness absences between the contingent and permanent employees and the corresponding rate ratios and their 95\% confidence intervals were determined by Poisson regression analysis $(30,31)$, in the same way as in previous studies $(11,32)$. The rate ratios were adjusted for demographic and occupational characteristics. Interaction terms were applied to test whether the associations between employment status and sickness absence were dependent on gender or health status.

\section{Results}

Descriptive statistics are presented for the subjects in table 1 . The majority of workers (88-89\%) in both groups were women. Compared with their colleagues in permanent jobs, contingent employees were younger, more often single, and more often had children under 10 years of age. The proportion of contingent employees was high among physicians and nurses and low among laboratory and X-ray staff and personnel in maintenance, cleaning and other corresponding activities. Contingent workers more often had part-time and shift work than permanent employees did. No differences were found in annual income between the two groups.

The descriptive statistics for health variables in table 2 show that employees in the younger age groups reported their health more favorably, had chronic diseases diagnosed by a physician less often, and had fewer psychiatric symptoms than the older workers did. The younger employees had fewer medically certified sickness absences but more self-certified sickness absences than the older employees did. There were no gender differences in self-reported health indicators, except that the women had a higher prevalence of minor psychiatric morbidity than the men. The women had also higher rates of both self-certified and medically certified sickness absences than the men.

\section{Employment status and health indicators}

In the adjusted models, contingent employment was associated with better self-rated health. No differences in 
the prevalence of diagnosed disease and minor psychiatric morbidity were found (table 3 ). No interactions

Table 1. Descriptive statistics for the background variables.

\begin{tabular}{|c|c|c|c|c|}
\hline \multirow[t]{2}{*}{ Variable } & \multicolumn{2}{|c|}{$\begin{array}{l}\text { Contingent } \\
\text { employees } \\
(\mathrm{N}=1264)^{\mathrm{a}}\end{array}$} & \multicolumn{2}{|c|}{$\begin{array}{l}\text { Permanent } \\
\text { employees } \\
(\mathrm{N}=4386)^{b}\end{array}$} \\
\hline & N & $\%$ & N & $\%$ \\
\hline \multicolumn{5}{|l|}{ Age $^{c}$} \\
\hline 19-29 years & 341 & 27 & 81 & 2 \\
\hline $30-39$ years & 483 & 38 & 953 & 22 \\
\hline $40-49$ years & 292 & 23 & 1671 & 38 \\
\hline $50-63$ years & 148 & 12 & 1681 & 38 \\
\hline \multicolumn{5}{|l|}{ Gender } \\
\hline Male & 139 & 11 & 535 & 12 \\
\hline Female & 1125 & 89 & 3851 & 88 \\
\hline \multicolumn{5}{|l|}{ Marital status } \\
\hline Unmarried or noncohabiting & 354 & 28 & 940 & 22 \\
\hline Married or cohabiting & 901 & 72 & 3417 & 78 \\
\hline \multicolumn{5}{|l|}{ Children } \\
\hline $\begin{array}{l}\text { No children }<10 \text { years } \\
\text { of age }\end{array}$ & 850 & 67 & 3399 & 77 \\
\hline $\begin{array}{l}\text { One or more children } \\
<10 \text { years of age }\end{array}$ & 414 & 33 & 987 & 23 \\
\hline \multicolumn{5}{|l|}{ Occupational group } \\
\hline Physicians & 109 & 9 & 289 & 7 \\
\hline Nurses & 680 & 54 & 2135 & 49 \\
\hline Other professionals & 40 & 3 & 170 & 4 \\
\hline Laboratory and X-ray staff & 142 & 11 & 621 & 14 \\
\hline Administrative staff & 133 & 11 & 533 & 12 \\
\hline Maintenance, cleaning, etc & 156 & 12 & 638 & 14 \\
\hline \multicolumn{5}{|l|}{ Hours of work } \\
\hline Full-time & 1056 & 86 & 4187 & 97 \\
\hline Part-time & 177 & 14 & 135 & 3 \\
\hline \multicolumn{5}{|l|}{ Work schedule } \\
\hline Day work & 485 & 39 & 2100 & 48 \\
\hline Shift work & 771 & 61 & 2256 & 52 \\
\hline
\end{tabular}

${ }^{a}$ Mean annual income FIM 131000.

b Mean annual income FIM 131000.

c The $25 \%$ quartiles for the contingent and permanent employees were 19-29 years and 21-39 years, respectively. The corresponding $75 \%$ quartiles were $43-61$ years and 53-63 years. The mean age was 36 years for the contingent employees and 46 years for the permanent employees. were evident with employment status and gender in the adjusted models.

\section{Employment status and sickness absence}

An interaction effect between gender and self-certified sickness absence was found $(\mathrm{P}=0.004)$; therefore further analyses on self-certified sickness absence were performed separately for the men and women (table 4). For the men, the rate ratios for self-certified sickness absence showed a slightly higher absence rate for the contingent workers. Among the women, the contingent employees took fewer short-term sickness absences than the permanent employees did. In relation to medically certified sickness absences, no interaction with employment status and gender was found. Contingent employees had a lower level of medically certified sickness absences than the permanent employees did.

No significant interactions for employment status and health with self-certified sickness absence were observed, but the association between employment status and medically certified sickness absence was moderated by all three health indicators. P-values for the interaction terms were employment status $\times$ self-rated health $(\mathrm{P}=0.008)$, employment status $\times$ diagnosed chronic diseases $(\mathrm{P}<0.001)$, and employment status $\times$ minor psychiatric morbidity $(\mathrm{P}<0.001)$. The associations of selfrated health, diagnosed chronic disease, and minor psychiatric morbidity with medically certified sickness absence were stronger among the permanent employees than among the contingent workers (figure 1).

\section{Discussion}

The results of our study indicate that contingent employment is associated with better self-rated health than permanent employment is. No difference was found in the prevalence of diagnosed diseases and minor psychiatric morbidity between the two groups. Contingent employ-

Table 2. Descriptive statistics of the health variables and sickness absences by age and gender.

\begin{tabular}{|c|c|c|c|c|c|c|c|c|c|}
\hline \multirow[t]{2}{*}{ Characteristic } & \multirow{2}{*}{$\begin{array}{l}\text { Total } \\
\text { (N) }\end{array}$} & \multicolumn{2}{|c|}{$\begin{array}{l}\text { Self-rated } \\
\text { health status } \\
\text { poor or average }\end{array}$} & \multicolumn{2}{|c|}{$\geq 1$ diagnosed diseases } & \multicolumn{2}{|c|}{$\begin{array}{l}\text { Caseness of minor } \\
\text { psychiatric morbidity }\end{array}$} & \multirow{2}{*}{$\begin{array}{l}\text { Number of self- } \\
\text { certified sickness } \\
\text { absence spells per } \\
100 \text { person-years }\end{array}$} & \multirow[t]{2}{*}{$\begin{array}{l}\text { Number of medically } \\
\text { certified sickness } \\
\text { absence spells per } \\
100 \text { person-years }\end{array}$} \\
\hline & & $N$ & $\%$ & N & $\%$ & N & $\%$ & & \\
\hline \multicolumn{10}{|l|}{ Age } \\
\hline 19-29 years & 422 & 30 & 7 & 87 & 21 & 79 & 19 & 191 & 72 \\
\hline $30-39$ years & 1436 & 170 & 12 & 412 & 29 & 303 & 22 & 180 & 70 \\
\hline $40-49$ years & 1963 & 311 & 16 & 798 & 42 & 385 & 20 & 140 & 65 \\
\hline $50-63$ years & 1829 & 535 & 30 & 1094 & 62 & 445 & 25 & 129 & 84 \\
\hline \multicolumn{10}{|l|}{ Gender } \\
\hline Male & 674 & 132 & 20 & 288 & 44 & 127 & 19 & 92 & 47 \\
\hline Female & 4976 & 914 & 19 & 2103 & 44 & 1085 & 22 & 157 & 77 \\
\hline
\end{tabular}


Table 3. Odds ratios (OR) of the health outcomes for the contingent employees and the permanent employees. $(95 \% \mathrm{Cl}=95 \% \mathrm{confi}-$ dence interval)

\begin{tabular}{|c|c|c|c|c|c|c|c|c|c|c|c|c|}
\hline \multirow[t]{3}{*}{ Type of employment } & \multicolumn{4}{|c|}{ Self-rated health poor or average } & \multicolumn{4}{|c|}{$\geq 1$ diagnosed diseases } & \multicolumn{4}{|c|}{ Caseness of minor psychiatric morbidity } \\
\hline & \multicolumn{2}{|c|}{ Unadjusted } & \multicolumn{2}{|c|}{ Adjusted $^{\mathrm{a}}$} & \multicolumn{2}{|c|}{ Unadjusted } & \multicolumn{2}{|c|}{ Adjusteda } & \multicolumn{2}{|c|}{ Unadjusted } & \multicolumn{2}{|c|}{ Adjusted ${ }^{a}$} \\
\hline & $\mathrm{OR}$ & $95 \% \mathrm{Cl}$ & $\mathrm{OR}$ & $95 \% \mathrm{Cl}$ & $\mathrm{OR}$ & $95 \% \mathrm{Cl}$ & $\mathrm{OR}$ & $95 \% \mathrm{Cl}$ & $\mathrm{OR}$ & $95 \% \mathrm{Cl}$ & $\mathrm{OR}$ & $95 \% \mathrm{Cl}$ \\
\hline Permanent & $\begin{array}{l}1.0 \\
0.46\end{array}$ & $0.38-0.56$ & $\begin{array}{l}1.0 \\
0.76\end{array}$ & $0.62-0.94$ & $\begin{array}{l}1.0 \\
0.55\end{array}$ & $0.48-0.62$ & $\begin{array}{l}1.0 \\
0.92\end{array}$ & $078-1.07$ & $\begin{array}{l}1.0 \\
0.96\end{array}$ & 0.82-1.11 & $\begin{array}{l}1.0 \\
1.06\end{array}$ & $089-126$ \\
\hline
\end{tabular}

a Adjusted for age, gender, marital status, having children $<10$ years of age, occupational group, hours of work, and work schedule.

Table 4. Self-certified and medically certified sickness absences of the contingent and permanent employees. $(\mathrm{RR}=\mathrm{rate}$ ratio, $95 \% \mathrm{Cl}=$ $95 \%$ confidence interval)

\begin{tabular}{|c|c|c|c|c|}
\hline & \multicolumn{2}{|c|}{ Unadjusted } & \multicolumn{2}{|c|}{ Adjusted a } \\
\hline & $\mathrm{RR}$ & $95 \% \mathrm{Cl}$ & $\mathrm{RR}$ & $95 \% \mathrm{Cl}$ \\
\hline \multicolumn{5}{|c|}{ Self-certified sickness absence ${ }^{b}$} \\
\hline \multicolumn{5}{|l|}{ Men } \\
\hline Permanent employees & 1.0 & & 1.0 & . \\
\hline Contingent employees & 1.49 & $1.28-1.73$ & 1.22 & $1.02-1.46$ \\
\hline \multicolumn{5}{|l|}{ Women } \\
\hline Permanent employees & 1.0 & & 1.0 & \\
\hline Contingent employees & 1.01 & $0.96-1.06$ & 0.90 & $0.85-0.95$ \\
\hline \multicolumn{5}{|c|}{ Medically certified sickness absence } \\
\hline Permanent employees & 1.0 & & 1.0 & \\
\hline Contingent employees & 0.71 & $0.66-0.76$ & 0.77 & $0.71-0.84$ \\
\hline
\end{tabular}

${ }^{a}$ Adjusted for age (gender in medically certified sickness absence), marital status, having children $<10$ years of age, occupational group, hours of work, work schedule, and self-rated health.

b Significant interaction $(P=0.004)$ with gender.
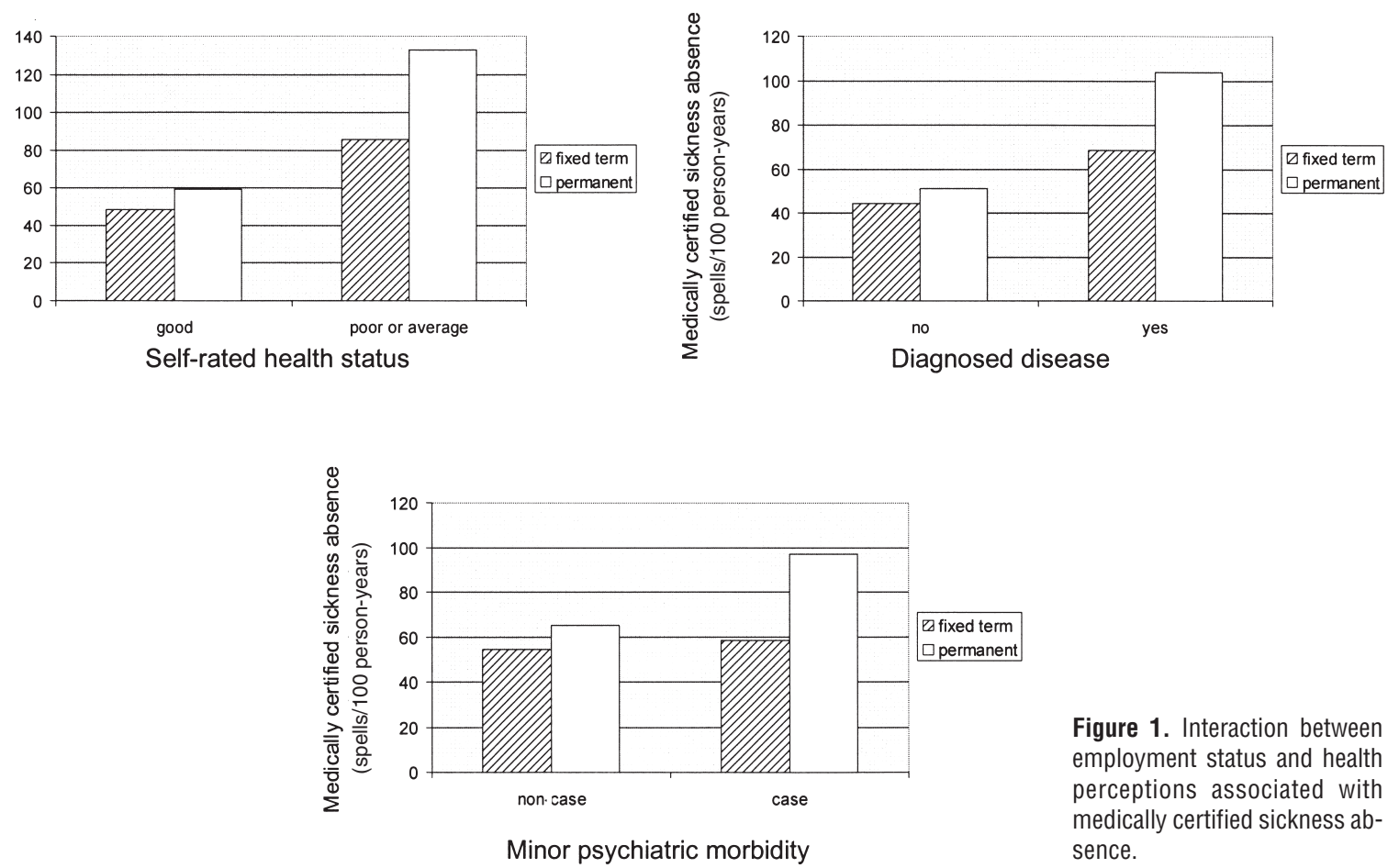

Figure 1. Interaction between employment status and health perceptions associated with medically certified sickness absence.

ment was also associated with lower levels of self-certified (among women) and medically certified sickness absences. Furthermore, medically certified sickness ab- sences were less affected by health problems among the contingent employees than among workers with permanent job contracts. 


\section{Self-reported health status}

The observation of better self-rated health among the contingent workers is in line with Swedish findings on contingent hospital personnel, who reported fewer somatic complaints than did permanent employees (1). In our study, no difference was found for mental health between the contingent and permanent employees; this finding is also in agreement with the Swedish study. Two studies have suggested that work-related fatigue and musculoskeletal symptoms (12) and mental distress (13) are more common among contingent workers than among permanent ones. The first study has been on employees from several European countries, and the second study investigated a patient population. In both of the studies the subjects were not entirely hospital employees.

The study context and sample of our study were similar to those of a Swedish hospital study (1). Both in Finland and in Sweden, data were collected on personnel in public hospitals in a period characterized by structural changes in the public health sector to improve effectiveness $(20,33)$. As a consequence of the economic decline between 1991 and 1995, unemployment in Finland rose from $3 \%$ to $16 \%$ at its highest, and it was still $11 \%$ in 1998 , at the time of the study (34), indicating competition for jobs. The need to increase flexibility in worklife affected employment contracts; nearly all the new work agreements were made on a fixed-term basis. For example, in 1995-1996 only 1\% of the new job contracts were permanent in Finnish hospitals (35).

In such a context, there may be stronger health selection out of work for contingent employees than for employees with permanent job contracts. Health selection is a process in which healthy people are more likely to move up and unhealthy people to move down the social and occupational hierarchy (36). There is strong evidence on health-related selective mechanisms for labor force mobility - from employment to unemployment (37-41), from unemployment to re-employment $(41,42)$, in educational achievement $(43,44)$, and in occupational mobility (45). According to the health selection assumption, there may be a tendency for organizations to prefer the renewal of fixed-term job contracts for workers with good health.

An alternative explanation for the better self-rated health among contingent employees relates to response style. Nonpermanent employees may be more reluctant to report health problems in spite of being assured of confidentiality (46). Some of the respondents reported this in the qualitative section of the survey, for example "A high proportion of the personnel has a fixed-term job contract. In our department we have discussed the way in which people answered the questionnaire. Fixed-term employees do not dare answer some questions honestly because they are afraid of losing their jobs" (nurse, 50 years of age, permanent employee).

\section{Sickness absences}

In general, contingent employees had a significantly lower rate of sickness absence than the permanent staff. We statistically partialled out the confounding effects of demographic and work-related characteristics. Therefore, in this study, the differences in family relations, occupational groups, workhours, and work schedule did not confound the results. In addition, the lower absence rates among the contingent employees than among the employees with a permanent job contract remained even after adjustment for differences in self-rated health between the groups.

A lower rate of self-certified sickness absence was evident among the women with contingent employment. A high proportion of the men in this study comprised physicians $(31 \%)$, who have low absence rates in general (47). This trend may have led to a constricted variation in sickness absences for the men.

Medically certified absence from work was less determined by health problems among the contingent workers than among the permanent employees. Our findings showed that the caseness of poor self-rated health, chronic diseases, and minor psychiatric morbidity was less strongly associated with sickness absence among the contingent employees. This finding was not due to better health for the cases among the contingent workers; no differences were found between the cases of contingent employees and the cases of permanent employees in the mean values of poor self-rated health, the number of chronic diseases, and the scores of minor psychiatric morbidity.

Kristensen (48) has suggested that, in relation to sickness absence, a person should be considered "a conscious actor who makes choices within a given social framework". Thus the difference in absence rates between the contingent and permanent workers may be related to different thresholds of taking sick leave in these two groups. Both positive and negative incentives may lead contingent employees to be present at work (ie, desire to have the work contract renewed or hope of getting a permanent job, as well as fear of dismissal or other negative sanctions from colleagues or management). In our study, for example, one of the contingent respondents who had recently fallen ill, described her situation as follows: "Substitutes have a hard time it's better not to take sick leaves" (nurse, 32 years of age, fixed-term employee).

Earlier studies on sickness absence rates before and after insecurity-inducing organizational changes have shown a significant increase in long-term sickness absence $(10,11,16)$, but a decrease in short-term sickness 
absence among the survivors (49). These studies, however, have focused on core employees. In a study of Beale \& Nethercott (9), sickness absence dropped under the threat of redundancy among employees under 40 years of age, and this decrease led the authors to conclude that younger employees have more to fear because of the "last hired first fired" principle of organizations.

However, it is also possible that our results were not associated with presenteeism among contingent workers, but rather with unnecessarily high absenteeism among the permanent staff. These issues are of major importance for future research on sickness absenteeism.

\section{Limitations}

A limitation of this study was the reliance on a crosssectional design that restrained us from drawing any firm causal conclusions about the role of contingent employment in health and sickness absence. The strengths, on the other hand, are its large sample size, the use of both self-reported and registered data, the possibility to make comparisons between contingent and permanent employees, and the statistical control for potential confounding due to variation in demographic and work-related factors. Such an approach has rarely been applied in previous studies.

\section{Concluding remarks}

Our data extend existing knowledge on the health status and sickness absence of contingent employees. It is likely that the differentiation and flexibility of the labor market will continue. This trend makes workforce in the barrier zone of contingent work arrangements a significant target group for research on public health (3). The results suggest better self-rated health and lower sickness absence rates for contingent employees than for workers with permanent job contracts. The difference in self-rated health may reflect stronger health selection out of the work among contingent employees. The difference in sickness absence between the groups seems not only to be associated with actual differences in health, but also with different thresholds of taking sick leave or working while ill.

\section{Acknowledgments}

This study was supported by grants from the Academy of Finland (project 44968 ), the Finnish Work Environment Fund, and the participating hospitals.

\section{References}

1. Sverke M, Gallagher DG, Hellgren J. Job stress, well-being, and work attitudes among employees with different employment contracts. In: Isaksson $\mathrm{K}$, Hogstredt $\mathrm{C}$, Eriksson $\mathrm{C}$, Theorell T, editors. Health effects of the new labour market. New York (NY): Kluwer Academic /Plenum Publishers, 2000:145-67.

2. Letorneux V. Precarious employment and working conditions in the European Union. European Foundation for the Improvement of Living and Working Conditions. Luxembourg: Office for Official Publications of the European Communities, 1997.

3. Aronsson G. Influence of worklife on public health. Scand J Work Environ Health 1999;25:597-604.

4. Klein Hesselink DJ, van Vuuren T. Job flexibility and job insecurity: the Dutch case. Eur J Work Organ Psychol 1999;8:273-93.

5. Kinnunen U, Nätti J. Job insecurity in Finland: antecedents and consequences. Eur J Work Organ Psychol 1994;4:297321.

6. Rosenblatt Z, Ruvio A. A test of a multidimensional model of job insecurity: the case of Israeli teachers. J Organ Behav 1996;17:587-605.

7. Ferrie JE, Shipley MJ, Marmot MG, Stansfield S, Smith GD. Health effects of anticipation of job change and non-employment: longitudinal data from the Whitehall II study. BMJ 1995;311:1264-9.

8. Ferrie JE, Martikainen P, Shipley MJ, Marmot MG, Stansfeld SA, Smith GD. Employment status and health after privatisation in white collar civil servants: prospective cohort study. BMJ 2001;322:1-7.

9. Beale N, Nethercott S. Certificated sickness absence in industrial employees threatened with redundancy. BMJ 1988;296:1508-10.

10. Kivimäki M, Vahtera J, Thomson L, Griffiths A, Cox T, Pentti J. Psychosocial factors predicting employee sickness absence during economic decline. J Appl Psychol 1997;82:858-72.

11. Kivimäki M, Vahtera J, Pentti J, Ferrie JE. Factors underlying the effect of organisational downsizing on health of employees: longitudinal cohort study. BMJ 2000;320:971-5.

12. Benavides FG, Benach J, Diez-Roug AV, Roman C. How do types of employment relate to health indicators? Findings from the second European survey on working conditions. J Epidemiol Community Health 2000;54:494-501.

13. Martens MFJ, Nijhuis FJN, van Boxtel MPJ, Knottnerus JA. Flexible work schedules and mental and physical health: a study of a working population with non-traditional working hours. J Organ Behav 1999;20:35-46.

14. Marmot MG, Feeney A, Shipley M, North F, Syme SL. Sickness absence as a measure of health status and functioning: from the UK Whitehall II study. J Epidemiol Community Health $1995 ; 49: 124-30$.

15. Briner RB. ABC of work-related disorders: absence from work. BMJ 1996;313:874-7.

16. Knutsson A, Goine H. Occupation and unemployment rates as predictors of long term sickness absence in two Swedish counties. Soc Sci Med 1998;47:25-31.

17. Cooper CL. The changing psychological contract at work [editorial]. Work Stress 1998;12:97-100.

18. Schabracq MJ, Winnubst JAM, Cooper CL. Preface. In: Schabracq MJ, Winnubst JAM, Cooper CL, editors. Handbook 
of work and health psychology. Chichester: Wiley, 1996.

19. Aronsson G, Gustafsson K, Dallner M. Sick but yet at work: an empirical study of sickness presenteeism. J Epidemiol Community Health 2000;54:502-9.

20. Sutela H, Vänskä J, Notkola V. Pätkätyöt Suomessa 1990luvulla [Contingent employment in Finland in 1990s]. Helsinki: Tilastokeskus, 2000. Työmarkkinat 1.

21. — Työsopimuslaki. L23.5.1997/459, 28.1§: Suomen laki II [Employment contract law: statute of Finland II]. Helsinki: Kauppakamari Oy ja Lakimiesliiton Kustannus, 2000;2028.

22. Idler EL, Benyamini Y. Self-rated health and mortality: a review of twenty-seven community studies. J Health Soc Behav 1997;38:21-37.

23. Blaxter M. Evidence on inequality in health from a national survey. Lancet 1987;2:30-3.

24. Idler EL, Angel RJ. Self-rated health and mortality in the NHANES-I Epidemiologic Follow-up Study. Am J Public Health 1990;80:446-52.

25. Marmot MG, Smith GD, Stansfeld S, Patel C, North F, Head $\mathrm{J}$, et al. Health inequalities among Britisih civil cervants: the Whitehall II study. Lancet 1991;337:1387-93.

26. Miilunpalo S, Vuori I, Oja P, Pasanen M, Urponen H. Selfrated health as a health measure: the predictive value of selfreported health status on the use of physician services and on mortality in the working age population. J Clin Epidemiol 1997;50:517-28.

27. Vahtera J, Pentti J, Uutela A. The effect of objective job demands on registered sickness absence spells: do personal, social and job-related resources act as moderators? Work Stress 1996;10:286-308.

28. Goldberg DP. The detection of psychiatric illness by questionnaire. London: Oxford University Press, 1972. Maudsley monograph no 21.

29. Goldberg D, Williams P. A user's guide to the general health questionnaire. Berkshire (UK): NFER-Nelson Publishing Co, 1988.

30. SAS Technical Report P-243. SAS/STAT software: the genmod procedure, release 6.09. Cary (NC): SAS Institute Inc., 1993.

31. Cohen J, Cohen P. Applied multiple regression/correlation analysis for the behavioral sciences. Erlbaum (NJ): Hillsdale, 1983.

32. North F, Syme SL, Feeney A, Head J, Shipley MJ, Marmot MG. Explaining socioeconomic differences in sickness absence: the Whitehall II Study. BMJ 1993;306:361-6.

33. Öhrming J, Sverke M. Etablerade sjukhus och nya driftsformer: delrapport från en tvärvetenskaplig studie av $\mathrm{S}: \mathrm{t}$ Görans Sjukhus Ab och Södertälje sjukhus [Established hospitals and new modes of management: part report from an interdisciplinary study of two Swedish emergency hospitals]. Stockholm: School of Business, 1996. Research reports, 1996:10.
34. Tilastokeskus. Työttömyys, 1975-1998: Suomen tilastollinen vuosikirja, 1999. [Unemployment 1975-1998: statistical yearbook of Finland 1999]. Helsinki: Tilastokeskus, 1999:349.

35. Ailasmaa R. Sosiaali- ja terveydenhuollon henkilöstö kuntasektorilla 1996. [Local government employees in social and health services 1996]. Stakes Tilastotiedote 1997;24:2-11.

36. Blane DB. An assessment of the Black Report's explanation of health inequalities. Sociol Health Illness 1985;7:423-45.

37. Klein-Hesselink DJ, Spruit IP. The contribution of unemployment to socioeconomic health differences. Int J Epidemiol 1992;21:329-37.

38. Leino-Arjas P, Liira J, Mutanen P, Malmivaara A, Matikainen E. Predictors and consequences of unemployment among construction workers: prospective cohort study. BMJ 1999;319:600-5.

39. Mastekaasa A. Unemployment and health: selection effects. J Community Appl Soc Psychol 1996;6:189-205.

40. Ferrie JE. Labour market status, insecurity and health. J Health Psychol 1997;2:373-97.

41. Janlert U. Unemployment as a disease and diseases of the unemployed. Scand J Work Environ Health 1997;23 suppl 3:79-83.

42. Claussen B, Björndal A, Hjort P. Health and re-employment in a two year follow up of long term unemployed. J Epidemiol Community Health 1993;47:14-8.

43. Koivusilta L, Rimpelä A, Rimpelä M. Health status: does it predict choice in further education? J Epidemiol Community Health 1995;49:131-8.

44. Van der Lucht F, Groothoff J. Social inequalities and health among children aged 10-11 in the Netherlands: causes and consequences. Soc Sci Med 1995;40:1305-11.

45. Östlin P. Negative health selection into physically light occupations. J Epidemiol Community Health 1988;42:152-6.

46. Aronsson G, Gustafsson K. Kritik eller tystnad - en studie av arbetsmarknads- och anställningsförhållandens betydelse för arbetsmiljökritik [Criticism or silence - a study on the significance of working market and employment conditions for criticism about working environment] Arbetsmarknad Arbetsliv 1999;5:189-206.

47. Kivimäki M, Sutinen R, Elovainio M, Vahtera J, Räsänen K, Töyry S, et al. Sickness absence in hospital physicians: 2 year follow up study on determinants. Occup Environ Med 2001;58:361-6.

48. Kristensen TS. Sickness absence and work strain among Danish slaughterhouse workers: an analysis of absence from work regarded as coping behaviour. Soc Sci Med 1991;1:15-27.

49. Vahtera J, Kivimäki M, Pentti J. Effect of organisational downsizing on health of employees. Lancet 1997;350:1124-8.

Received for publication: 23 May 2001 